J. Lake Sci. (湖泊科学), 2014, 26(6): 822-828

http: //www. jlakes.org. E-mail : jlakes@niglas.ac.cn

(C) 2014 by Journal of Lake Sciences

\title{
太湖地区农业源污染核算研究进展
}

\author{
高 波 ${ }^{1,2}$, 颜晓元 ${ }^{2}$, 姜小三 ${ }^{1}$,遆超普 ${ }^{2 * *}$ \\ ( 1 : 南京农业大学资源与环境科学学院,南京 210095) \\ (2:中国科学院南京土壤研究所土壤与农业可持续发展国家重点实验室,南京 210008)
}

\begin{abstract}
摘 要: 太湖地区水体污染严重,控制太湖污染、改善太湖水质,对发挥太湖的综合服务功能,促进全流域经济可持续发 展和社会稳定具有重要的战略意义. 充分把握和核算太湖地区农业源污染排放量、人河量及其时空分布是落实太湖地区 污染物科学减排从而进一步改善太湖水质的基础. 本研究总结和概述了太湖地区农业源污染现有的核算方法、产排污参 数、控制途径等, 结合太湖地区农业源污染构成、排放与布局的复杂情况, 提出综合运用各种核算研究方法, 充分考虑各 污染来源, 确定农业源污染的产污量、排污量和入河量, 并通过建立分期、分区、细分类型的农业源污染排放、人河参数, 为科学确定农业源污染减排指标以及制定减排措施提供依据.
\end{abstract}

关键词: 农业源污染;核算方法;参数研究;减排途径;太湖地区

\section{Research progress in estimation of agricultural sources pollution of the Lake Taihu region}

GAO Bo ${ }^{1,2}$, YAN Xiaoyuan ${ }^{2}$, JIANG Xiaosan ${ }^{1} \&$ TI Chaopu ${ }^{2}$

(1: College of Resources and Environment Science, Nanjing Agricultural University, Nanjing 210095, P. R. China)

(2: State Key Laboratory of Soil and Sustainable Agricultural, Institute of Soil Science, Chinese Academy of Sciences, Nanjing 210008, P. R. China)

Abstract: The Lake Taihu region, China, is highly developed, and water pollution has affected both the water supply and economic development of the region in recent years. It is important to understand and evaluate the quantity and spatial-temporal distribution of agricultural pollution to reduce the water pollution, improve the water quality and promote the economic development in this region. This paper reviewed the estimating methods, output coefficients and pollutant-controlled strategies of the agricultural sources pollution that have been widely applied. Considering the composition, emission and distribution of agricultural pollution sources in the Lake Taihu region, multiple methods, such as field monitoring and field survey, should be applied to estimate the agricultural pollution and their apportionments. It was significant to determine the coefficients of pollutant production, emission and discharge into rivers from cropland, livestock and aquaculture, and their differences in spatial and temporal distribution. Some specific suggestions and applicable measurements were put forward to reduce agricultural sources pollution in the Lake Taihu region. Keywords: Agricultural sources pollution; accounting method; parameter research; mitigation strategy ; Lake Taihu region

近几十年来随着点源污染的有效治理和控制, 农业源污染对水体的影响日益凸显,已成为水环境污染 的一个重要来源. van Drecht 等 ${ }^{[1]}$ 指出来自于农业源的氮对全球地表水污染的贡献为 $19 \% \sim 61 \%$; OECD 的 调查显示, 1990-2000 年间该组织内大约一半的成员国水体主要污染源来自农业,并且农业源污染的贡献 呈现增加的趋势 ${ }^{[2]}$. 我国农业源污染的程度和广度已超过欧美国家,并且愈演愈烈. 第一次全国污染普查显 示,农业源污染物总氮 $(\mathrm{TN})$ 和总磷 $(\mathrm{TP})$ 的排放量分别占排放总量的 $57.2 \%$ 和 $67.4 \%$, 化学需氧量 (COD) 的排放量也占到总量的 $43.7 \%{ }^{[3]}$. 农业源污染已经成为我国湖泊富营养化及水环境污染的最重要来源, 根 据国家环境保护部对太湖、巢湖、滇池的调查研究显示, 工业废水对进人水体的 TN 、TP 的贡献率仅为 $10 \%$

* 中国科学院知识创新工程重大项目 (KZZD-EW-10-04) 资助. 2013-12-16 收稿; 2014-05-05 收修改稿. 高波 (1989 ), 男, 硕士研究生; E-mail:gaobonj@163.com.

** 通信作者;E-mail:cpti@ issas. ac.cn. 
$16 \%$,大部分氮、磷来自于生活污水和农业源污染 ${ }^{[4]}$.

太湖是我国第三大淡水湖,湖面面积 $2338 \mathrm{~km}^{2}$, 太湖地区是我国人口最密集、经济最发达的地区之一. 2011 年太湖全流域总人口和 GDP 分别占全国的 $4.4 \%$ 和 $10.3 \%$, 人均 GDP 为全国平均的 2.3 倍 ${ }^{[5]}$. 随着经 济发展和人口增加, 太湖水环境问题日趋严峻, 由于氮、磷富集造成的蓝藻水华暴发事件连年发生, 由此造 成的水质型缺水以及生态环境恶化已成为威胁太湖地区经济可持续发展与供水安全的重大环境问题 ${ }^{[6]}$. 水 利部太湖流域管理局等单位对 2012 年太湖地区 32 个省界河流断面监测结果显示, 约有 $56 \%$ 的水体处于 V 类或劣 $\mathrm{V}$ 类, 主要污染指标仍为 $\mathrm{TP}$ 、氨氮 $\left(\mathrm{NH}_{3}-\mathrm{N}\right) 、 \mathrm{COD}$ 等 ${ }^{[7]}$.

大量研究显示农业源污染是造成太湖水体富营养化的主要因子. 金相灿等 ${ }^{[8]}$ 指出太湖地区污染源中来 自农业源的 TN 污染物占污染物总量的 $52.6 \%$; 同样,李荣刚等 ${ }^{[9]}$ 在太湖江苏地区的研究也显示,农业源 TN 占排放到水体中污染物总量的 $50 \%$ 左右. 杨林章等 ${ }^{[10]}$ 对太湖地区污染负荷来源的分析表明,农业 TN、TP 污 染所占的比重分别约为 $58 \% 、 40 \%$. 刘庄等 ${ }^{[11]}$ 的研究表明, 畜禽养殖和水产养殖是太湖流域农业源污染的 主要来源, 来自这二者的 TN、TP、COD 污染负荷分别占流域总污染负荷的 $43 \% 、 71 \% 、 65 \%$. 由此可见,控制 太湖地区农业源污染是治理太湖湖泊富营养化及改善太湖地区水环境的当务之急.

\section{1 农业源污染核算方法}

关于农业源污染的核算方法, 可具体分为模型模拟、调查分析与资料收集以及基于实验的野外监测 3 大类.

\section{1 模型模拟}

运用模型估算农业源污染是一种较为传统的方法,一直以来都得到了广泛的关注和推广. 近些年“3S” (即 RS、GIS 和 GPS) 技术的蓬勃发展, 有效扩大了模型在农业源污染研究中的适用范围. 目前国内外应用较 多的模型有 ANSWERS、CREAMS、AGNPS、WEPP、HSPF、SWAT 等. 其中, CREAMS ( chemicals, runoff and erosion from agricultural management systems) 是由美国农业部于 1980 年提出的一个连续模拟模型,它首次对非 点源污染的水文、侵蚀和污染物运移过程进行了系统的综合, 奠定了非点源污染模型发展的里程碑 ${ }^{[12]}$. AGNPS (agricultural nonpoint pollution source) 模型用于研究点源和非点源污染物对地表水和地下水质的潜在影 响, 适用于集水面积在 $200 \mathrm{~km}^{2}$ 以下的流域 ${ }^{[13]}$. SWAT ( soil and water assessment tool) 为流域尺度模型, 可以 预测不同的土壤、土地利用和管理措施对流域径流、泥沙负荷、农业化学物质运移等的长期影响,包括产流、 坡面汇流和河道汇流, 既可应用于以农业为主的集水区,也可帮助水资源管理者评价水质、营养物和杀虫剂 等非点源污染和相应的管理措施 ${ }^{[14]}$.

当前我国对面源污染的模拟研究以引进国外成熟且广泛应用的模型为主 ${ }^{[15-17]}$. 曾远等 ${ }^{[18]}$ 和高菲等 ${ }^{[19]}$ 利用 AGNPS 模型分别对太湖地区典型圩区和丘陵地区地表径流量和氮、磷流失负荷进行了定量计算, 并认 为该模型对磷浓度的模拟结果和实测值误差稍大;Zhang 等 ${ }^{[20]}$ 利用 SWAT 模型模拟了南太湖地区非点源污 染来源, 研究证明该模型效果较好; 针对整个太湖地区, 赖格英等 ${ }^{[21]}$ 利用分布式机理性的流域模型 SWAT, 模拟了 $1960 \mathrm{~s}$ 营养物质输移的时空分布, 研究认为由于很多输人数据无法直接获取, 必定导致模型模拟存在 不确定性和可能产生的误差,给模拟结果的可靠性带来一定影响.

尽管在进行农业源污染的量化研究以及影响评价和污染治理时, 模型模拟是一种有效和直接的研究方 法, 并具有进行时间和空间序列模拟的优势, 但是模型模拟也存在一些缺陷, 首先需要较多的验证参数, 另 外太湖地区河湖水面占 $16 \%$, 流域内水网密布,且水系之间的水量可以互相调节,水流没有固定的方向,使 得模型模拟的方法在该流域内难以整体推广应用.

\section{2 调查分析与资料收集}

由于具有覆盖面广、时效性强的特点, 调查和普查也是目前应用比较广泛的农业源污染研究手段之一. 该方法通过收集相关领域的文献资料和统计数据,选取合理的适用范围,探索各数据信息之间的相关关系，

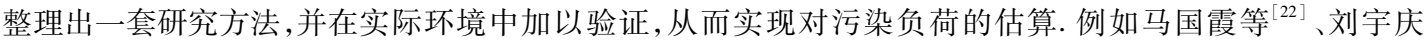
等 ${ }^{[23]}$ 利用普查数据,计算了我国内地 31 个省市自治区的农业面源污染总排放量. 在太湖地区, 刘庄等 ${ }^{[11]}$ 根 据 2007 年环太湖地区“两省一市” 的社会经济统计年鉴和农村统计年鉴再结合各污染源产污系数,最终计 
算得出太湖地区不同类型污染源的污染负荷量. 张利民等 ${ }^{[24]}$ 比较全面地调查了太湖地区望虞河西岸地区 氮、磷污染来源, 指出太湖地区望虞河西岸水体氮、磷污染严重, 问题突出. $\mathrm{Ti}$ 等 ${ }^{[25]}$ 利用第一次农业普查数 据结合统计年鉴估算了 2010 年太湖流域常熟市水体氮负荷, 并分析了氮的来源, 同时做了不确定性分析.

尽管调查分析与资料收集法可以较为直观地表达一个地区的整体污染情况, 但目前太湖地区农业源污 染的调查工作只是在零散的城市或个别流域内展开, 还缺乏流域性的系统普查分析, 而且以往的调查缺乏 规范、标准的农业源污染调查评估指标体系, 影响各次调查数据及评估结果的可靠性、可比性和可用性. 另 外, 调查与资料收集的方法也存在一定的问题和缺陷,例如在污染源负荷的估算上过度依赖产排污系数等; 而且调查的方法未考虑研究区域间的差异和污染物的动态迁移过程, 各项参数的获取均来自参考文献和统 计资料等,对于整个地区而言有一定的不确定性.

\section{3 野外监测}

农业源污染研究的关键是能否获取必要的基本数据(包括背景资料和降雨径流监测数据). 对于农业源 污染负荷的估算,国内外学者近年来做了大量相关的实地实验研究,且研究起步较早 ${ }^{[26-28]}$.

在太湖地区, Gao 等 ${ }^{[29]}$ 对一个典型的农业流域进行了氮的流失监测, 认为该流域内稻季流人水体的氮 为 $10.5 \mathrm{~kg} \mathrm{~N} / \mathrm{hm}^{2}$. 通过对水产养殖户进行采样监测, 宋学宏等 ${ }^{[30]}$ 分析了苏州地区池塘养殖产生水环境污染 的主要原因, 从池塘管理体制改革、科学生态养殖技术及养殖尾水处理等方面探讨了池塘养殖污水零排放 技术, 为苏州市养殖业面源污染的控制提供了对策和措施. 通过在太湖流域平原河网地区选择典型圩区开 展野外原位试验, 王鹏等 ${ }^{[31]}$ 研究了圩区氮素在自然降雨和径流驱动下的迁移特征, 建立了稻季农田氮素的 迁移通量与径流通量、施肥量及降雨距施肥时间间隔 3 者之间的定量化关系.

野外监测的方法是通过选取典型区域、罗列产污来源并进行野外监测, 确定各污染源的相关参数和产 排污过程, 从而估算出该地区的农业源污染负荷量以及相关影响因素. 由实验方法得到的相关估算值数据 可靠, 且时效性较好, 可用于对模型模拟和调查分析的验证. 但是野外监测一般研究区域范围较小, 如需扩 展到整个流域尺度, 要考虑环境变化等各类条件的影响, 野外干扰较大. 另外, 由于农业源污染是一种间歇 发生的, 随机性、突发性、不确定性很强的复杂过程, 所以基础数据收集工作的劳动强度大、效率低、周期长、 费用高.

\section{2 农业源污染的相关参数}

农业源污染的产排污系数一直以来都是国内外研究者们的研究重点, 通过对污染源产排污系数的测 算, 结合相关数据资料, 能够在一定程度上反映研究区域内的污染情况. 目前国内外研究者对于农业源产排 污系数的测算主要集中于农田径流和淋溶、禽畜养殖和水产养殖等方面.

\section{1 农田径流和淋溶}

国内外学者均对农田径流和淋溶系数作了有益的探讨和研究, 给出了一系列参数 ${ }^{[32-33]}$. 《第一次全国污染 源普查公报》分别根据土地利用情况、坡度、降雨等因素给定了淋溶和径流定位监测试验点的 372 个测算肥 料流失系数 ${ }^{[4]}$. 胡玉婷等 ${ }^{[34]}$ 从统计学角度分析核算出我国水田、旱地中 $\mathrm{TN}$ 的表观流失率. 在太湖地区,杨 蓓䔒等 ${ }^{[35]}$ 通过田间定位观测分析表明, 稻季农田磷以径流流失为主, 在较低传统施肥水平下 $\left(102 \mathrm{~kg} / \mathrm{hm}^{2}\right)$ 农田磷年流失量为 $5.33 \mathrm{~kg} / \mathrm{hm}^{2}$, 占施肥量的 $3.59 \%$, 稻季磷流失对水环境质量仍构成一定威胁; 郭智等 ${ }^{[36]}$ 采用田间小区定位试验研究了自然降雨条件下江苏稻麦两熟农田稻季养分径流流失系数, 结果表明常规施 肥条件下, 稻田径流流失 TN、TP 和速效钾的总量分别为 $11.29 、 0.19$ 和 $13.22 \mathrm{~kg} / \mathrm{hm}{ }^{2}$, 流失率分别为 $3.80 \% 、 0.21 \%$ 和 $9.80 \%$; Min 等 ${ }^{[37]}$ 指出太湖地区温室大棚蔬菜地不同施肥水平下氮淋溶的范围为 $11 \sim 123$ $\mathrm{kg} \mathrm{N} / \mathrm{hm}^{2}$; 太湖地区常规施肥下麦季和稻季的氮径流淋溶系数分别为 9.88 和 $1.87 \mathrm{~kg} \mathrm{~N} / \mathrm{hm}^{2}$, 分别占氮肥施 用量的 $5 \%$ 和 $0.3 \%$. Zhao 等 ${ }^{[38]}$ 对太湖地区典型的稻麦轮作农田进行为期 3 年的跟踪观测, 得出 $2007-$ 2010 年间该地区常规施肥水平下稻季总氮径流流失量分别为 $21.8 、 2.65$ 和 $19.2 \mathrm{~kg} / \mathrm{hm}^{2}$, 而麦季总氮流失量 则分别为 33.4、42.8 和 $58.7 \mathrm{~kg} / \mathrm{hm}^{2}$. Tian 等 ${ }^{[39]}$ 通过对不同肥料处理下的农田进行连续观测, 测算出稻麦轮 作农田生态系统中氮径流和淋溶年均损失在 $13.7 \sim 48.1 \mathrm{~kg} / \mathrm{hm}^{2}$ 之间, 由于各研究者实验设计不同, 所得 氮、磷流失量之间各有差异, 故将各实验中氮、磷径流损失率和淋溶损失率进行统计, 结果见表 1 、表 2 . 
表 1 太湖地区农田 TN、TP 径流损失率

Tab. 1 TN and TP runoff loss from cropland in the Lake Taihu region

\begin{tabular}{|c|c|c|c|c|}
\hline 研究地点 & 作物类型 & $\mathrm{TN}$ 径流损失率/\% & $\mathrm{TP}$ 径流损失率/\% & 参考文献 \\
\hline 上海市 & 水稻 & - & 3.59 & 杨蓓蓓等 ${ }^{[35]}$ \\
\hline 杭州市余杭区 & 水稻 & 4.88 & 0.69 & 聂泽宇[40] \\
\hline 溧水县 & 水稻 & 3.80 & 0.21 & 郭智等 ${ }^{[36]}$ \\
\hline \multirow[t]{2}{*}{ 常熟市 } & 水稻 & 1.30 & 2.02 & 谢学俭 ${ }^{[41]}$ \\
\hline & 小麦 & 1.30 & 3.01 & \\
\hline \multirow[t]{3}{*}{ 宜兴市 } & 蔬菜 & 0.43 & 3.27 & 李国栋等 ${ }^{[42]}$ \\
\hline & 小麦 & 11.77 & 1.85 & 朱普平等 ${ }^{[43]}$ \\
\hline & 水稻 & 1.70 & 0.33 & \\
\hline 溧阳市 & 水稻 & 2.49 & 0.97 & 夏小江等 ${ }^{[44]}$ \\
\hline
\end{tabular}

表 2 太湖地区农田 TN、TP 淋溶损失率

Tab. 2 TN and TP leaching loss from cropland in the Lake Taihu region

\begin{tabular}{|c|c|c|c|c|}
\hline 研究地点 & 作物类型 & $\mathrm{TN}$ 淋溶损失率/\% & $\mathrm{TP}$ 淋溶损失率/\% & 参考文献 \\
\hline \multirow[t]{2}{*}{ 溧水县 } & 小麦 & 5 & - & 郭智等 ${ }^{[36]}$ \\
\hline & 水稻 & 0.3 & - & \\
\hline \multirow[t]{3}{*}{ 宜兴市 } & 蔬菜 & 14.14 & - & Min 等 ${ }^{[37]}$ \\
\hline & 水稻 & 2.74 & - & Zhao 等 $[45]$ \\
\hline & 小麦 & 0.72 & - & \\
\hline 无锡市滨湖区 & 水稻 & 1.3 & - & 俞映倞等 $[46]$ \\
\hline \multirow[t]{2}{*}{ 常熟市 } & 水稻 & 0.76 & 0.4 & 张静等 ${ }^{[47]}$ \\
\hline & 小麦 & 5.65 & - & \\
\hline
\end{tabular}

尽管太湖地区关于农田氮径流淋溶系数的研究很多, 但是关于磷、COD 等污染物参数的研究较少; 另 外,农田的径流淋溶参数多关于稻麦等主要粮食作物, 而对于蔬菜、茶果园的研究较少.

\section{2 禽畜养殖}

随着居民消费需求的增长, 禽畜养殖业污染已成为农业源污染的重要组成部分, 禽畜养殖场污水中含 有大量的污染物质, 其污水生化指标极高, 如猪粪尿混合排出物的 COD 、生物耗氧量以及铵态氮最高值分别 达到 $81 、 17 \sim 32$ 和 2.5 4.0 g/ $\mathrm{L}^{[48]}$. 目前国内对于规模化养殖场各污染物排放量的核算已得到诸多学者的 重视 ${ }^{[49-50]}$. 在太湖地区, 关于禽畜养殖业污染的研究不多, 蒋治国等 ${ }^{[51]}$ 参照第一次全国污染普查农业源产排 污系数测算实施方案, 测定了太湖地区某个养殖场的生猪排污系数, 认为该养殖场生猪不同生育阶段的 $\mathrm{TN} 、 \mathrm{TP}$ 和 COD 排污系数分别为 $12.07 \sim 20.70 、 5.17 \sim 8.50$ 和 $7.44 \sim 17.70 \mathrm{~g} /$ (头 $\cdot \mathrm{d}$ ). 尽管该计算方法区 分了产污系数和排污系数, 但要获得较为科学的产物系数还需要分畜种、分阶段进行测定. 关于禽畜养殖产 排污系数的研究在太湖地区不多,而且大部分农业源估算中的禽畜养殖排放系数都是通过查阅资料获 取的.

\section{3 水产养殖}

我国是水产养殖业大国,农业部发布的《2010 年全国渔业经济统计公报》 ${ }^{[52]}$ 显示, 2010 年全国水产养 殖面积为 $7645.22 \times 10^{3} \mathrm{hm}^{2}$, 占耕地面积的 $6.3 \%$. 太湖地区是典型的河网平原地区, 淡水资源丰富, 渔业水 平较发达, 大部分养殖户为追求高产, 往往投放过量的犆料, 过量的营养成分导致鱼塘水中氮、磷浓度偏高. 淡水养殖过程中, 随着鱼塘换水、出泥, 大量氮、磷进人水环境中. 有研究认为鱼塘系统饵料氮仅 $13.9 \%$ 转化 为渔产品, 另有 $13.4 \%$ 沉积于底泥, 水体及损失部分占 $72.7 \%{ }^{[53]}$. 由此可见,水产养殖也是太湖地区水污染 的重要来源之一,近年来也得到了诸多学者的重视. 在太湖地区, 施炜纲等 ${ }^{[54]}$ 研究了草型湖泊 (东太湖) 蟹、 鱼网围混养对水域的氮、磷污染, 水产养殖过程中由于投放蟹、鱼种和饲料形成的 TN、TP 输人量分别为 
$27.9 、 4.4 \mathrm{~kg} / \mathrm{hm}^{2}$. 据 2001 年调查, 陈家长等 ${ }^{[55]}$ 按物料平衡法计算得出 $1 \mathrm{hm}^{2}$ 养蟹池塘向环境排放的 TN、TP 分别为 $27.08 、 7.85 \mathrm{~kg}$, 太湖地区池塘养蟹向环境中年排放 TN、TP 分别为 308.12 和 $89.32 \mathrm{t}$. 按池塘进排水 实测值计算, 太湖地区池塘养蟹外排水中 TN、TP 浓度增量分别为 $0.34 、 0.05 \mathrm{mg} / \mathrm{L}$. 结合全国污染源普查活 动, 以苏州市养殖老区东山镇养殖池塘为典型, 宋学宏等 ${ }^{\left[{ }^{[0]}\right.}$ 指出 1 个养殖周期中, 养殖池塘通过沟渠排人外 界的 TN、TP 平均含量分别为 $21.25 、 2.34 \mathrm{~kg} / \mathrm{hm}^{2}$.

尽管目前关于水产养殖对水体污染的研究有所展开, 但多集中于产排污系数, 对于污染物流人水体部 分的估算研究较少, 致使研究存在一定的缺陷. 另外, 目前的研究多集中于典型池塘、半开放水体等, 关于整 个流域的研究较少,尤其是在水产养殖污染空间分布方面的研究较为欠缺.

\section{3 农业源污染防控的建议和对策}

目前农业源污染问题已逐渐得到世界各国的重视, 研究者们也提出多项防控措施并加以实际运用, 美 国国家环保局早在 $1970 \mathrm{~s}$ 提出 BMPs (best management practices), 即最优管理措施. 该理论旨在降低非点源 污染负荷, 均衡社会效益与环境效益, 被认为是目前防治或减少农业非点源污染最有效和最实际的措施 ${ }^{[56]}$. BMPs 要求根据区域特征、污染状况等因地制宜地实施 BMPs 中所包含的具体管理措施和工程措施, 对于整 个太湖流域各地污染程度以及经济发展水平等差异有着很好的参考作用. 国内学者杨林章等 ${ }^{[10]}$ 对我国现有 的农村污水的治理、农村垃圾的处置以及农田化肥农药的残留控制技术作了详细介绍, 并总结和提炼出农 业面源污染治理的“4R” 理论, 即源头减量 (reduce)、过程阻断 (retain)、循环利用 (reuse) 和生态修复 (restore), “4R” 理论同样强调因地制宜的治理理念, 将治理和修复运用在污染物的排放、迁移、污染成灾等过程 中, 已在太湖地区成功运用于示范工程, 取得较好的成果. 寻求合理的化肥使用量是兼顾粮食高产和环境保 护的一个重要话题 ${ }^{[57-58]}$, 尤其在太湖地区高氮肥投人背景下, 合理降低化肥用量势在必行. 对此, 国家农业 部门从 2005 年开始全面推广测土配方施肥. 测土配方施肥可有效缓解过量施肥和施肥比例不合理问题, 减 少养分流失的同时也带动了有机肥的增施 ${ }^{[59]}$. 有机肥可改良土壤的物理、化学和生物特性, 目前商品有机肥 料含有植物所需的各种营养元素和有机质, 因此在作物生长过程中增加有机肥的施用, 是太湖地区发展绿 色农业、保持生态环境安全的首选措施 ${ }^{[60]}$. 近年来, 利用生物工程措施降低农业面源污染的技术引起了各国 学者的关注 ${ }^{[61-62]}$. 目前此类技术主要包括生态浮床技术、水生生物技术和生态护坡技术, 利用植物或水生生 物的吸收、吸附、降解等作用以达到净化水质的目的, 尤其是水生生物修复技术可有效降低水体中氮、磷等 污染指标 ${ }^{[63]}$. 针对太湖地区河网密布、水资源丰富等特点, 可在一些农业集约化程度较高的区域如常州、无 锡等太湖一级保护区设立缓冲区试验点, 对太湖地区农业源污染的防控具有现实意义.

\section{4 总结与展望}

由于太湖地区河网密集, 各水系的汇流关系复杂, 单纯地使用模型、野外监测或者调查等方法不能较好 地核算出流域的农业源污染物产生、排放和人河量. 对于太湖氮素的输人量与输出量已有较多研究, 但各研 究所用的核算方法相差较远, 结果相差较大, 因此需要综合考虑多种方法结合的手段进行进一步的研究. 利 用模型模拟方法估算农业源污染负荷时, 应当与调查统计以及野外试验相结合, 以便更好地发挥其良好的 预测能力, 提高模拟数值的准确性. 目前, 对于太湖地区主要污染物系数的测算, 主要集中于污染源的产污 量和排污量, 而污染物对水体最终的影响程度应取决于污染物的人河量及其降解速率, 而不是单纯的产污 量. 因此, 应在目前产排污系数测算的基础上, 加强对污染物人河量的监测和估算, 研究污染物降解的速率 及其影响因素, 以确切掌握各污染物对水体的真实影响情况. 大量研究表明, 水产养殖业也是农业源污染的 一个重要来源, 尤其是在太湖地区, 水产养殖业在整个农业源污染中占有较大的比重, 而目前受重视程度不 高、管理不当等因素已经使得该地区水产养殖污染越来越严重. 未来应根据太湖地区整个流域特点作进一 步研究, 应用遥感技术, 结合种植业、畜禽养殖等其他农业源污染信息, 建立较为精确的农业源污染数据库, 合理反映具体区域内污染源污染的时间和空间变化特征, 以清晰展现污染物在流域内的迁移和转化过程, 建立分期、分区、细分类型的排放和人河参数, 为提出有效的防控措施和减排途径提供依据. 


\section{5 参考文献}

[ 1 ] van Drecht G, Bouwman AF, Knoop JM et al. Global modeling of the fate of nitrogen from point and nonpoint sources in soils, groundwater, and surface water. Global Biogeochemical Cycles, 2003, 17(4) : 1115.

[ 2 ] OECD. Environmental performance of agriculture in OECD countries since 1990, 2008. www. oecd. org/tad/env/indicatiors.

[ 3 ] 国家环境保护总局. 三河三湖水污染防治计划及规划. 北京: 中国环境科学出版社,2000.

[ 4 ] 中华人民共和国环境保护部,中华人民共和国国家统计局,中华人民共和国农业部. 第一次全国污染源普查公报, 2010. http://www. gov. cn/jrzg/2010 - 02/10/content_1532174htm.

[ 5 ] 水利部太湖地区管理局. 2011 太湖流域及东南诸河水资源公报,2012. http://www. tba. gov. cn/indexhtml.

[6 ] Qin BQ, Zhu GW, Gao G et al. A drinking water crisis in lake Taihu, China: linkage to climatic variability and lake management. Environmental Management, 2010, 45: 105-112.

[ 7 ] 水利部太湖流域管理局,江苏省水利厅,浙江省水利厅等. 2012 年太湖健康报告, 2013. http://www. tba. gov. cn: 89/web/indexjsp\#.

[8] 金相灿,叶 春,颜昌宙等. 太湖重点污染控制区综合治理方案研究. 环境科学研究,1999,12(5):1-5.

[9] 李荣刚,夏源陵,吴安之等. 江苏太湖地区水污染物及其向水体的排放量. 湖泊科学,2000,12(2):147-153.

[10］杨林章,施卫明,薛利红等. 农村面源污染治理的“4R” 理论与工程实践一一总体思路与 “4R”治理技术. 农业环境 科学学报, $2013, \mathbf{3 2}(1): 1-8$.

[11] 刘 庄,李维新,张毅敏等. 太湖流域非点源污染负荷估算. 生态与农村环境学报,2010,26(增刊 1):45-48.

[12] Knisel WG. CREAMS: A field-scale model for chemicals, runoff and erosion from agricultural management systems. USDA Conservation Research Report, 1980.

[13] Young RA, Onstad CA, Bosch DD et al. AGNPS: A nonpoint-source pollution model for evaluating agricultural watersheds. Journal of Soil and Water Conservation, 1989, 44(2) : 168-173.

[14] Neitsch SL, Arnold JG, Kiniry JR. Soil and water assessment tool user's manual: version 2000. Texas: Blackland Research Center, Texas Agricultural Experiment Station, 2002.

[15] 赵 刚,张天柱,陈吉宁. 用 AGNPS 模型对农田侵蚀控制方案的模拟. 清华大学学报: 自然科学版,2002,42(5): 705-707.

[16] 胡远安, 程声通, 贾海峰. 非点源模型中的水文模拟一一 - SWAT 模型在芦溪小流域的应用为例. 环境科学研究, 2003,16 ( 5 ) :29-32.

[17] 王吉苹, 曹文志. 应用 GLEAMS 模型评估我国东南地区农业小流域硝态氮的渗漏淋失. 生态与农村环境学报, 2007,23 ( 1 ) :28-32.

[18］曾 远,张永春,张龙江等. GIS 支持下 AGNPS 模型在太湖流域典型圩区的应用.农业环境科学学报,2006,25(3)： 761-765.

[19］高 菲,张文胜,刘 庄等. AnnAGNPS 模型在太湖流域丘陵区适用性研究. 人民长江, 2009,40(21):79-82.

[20] Zhang QL, Chen YX, Jelani G et al. Model AVSWAT apropos of simulating non-point source pollution in Taihu lake basin. Journal of Hazardous Materials, 2010, 174: 824-830.

[21] 赖格英, 于 革. 太湖流域 1960 年代营养物质输移的模拟评估研究. 中国科学院研究生院学报, 2007,24(6): 756-764.

[22] 马国霞,於 方,曹 东等. 中国农业面源污染物排放量计算及中长期预测. 环境科学学报,2012,32(2):489-497.

[23] 刘宇庆,刘 燕,杨晓东等. 扬州市邗江区农业面源污染现状与对策浅析. 农学学报,2013,3(1):41-44.

[24] 张利民,王 水,韩 敏等. 太湖流域望虞河西岸地区氮磷污染来源解析及控制对策. 湖泊科学, 2010,22 (3): 315-320.

[25] Ti CP, Xia YQ, Pan JJ et al. Nitrogen budget and surface water nitrogen load in Changshu: a case study in the Taihu Lake region of China. Nutrient Cycling Agroecosystems, 2011, 91 (1) : 55-66.

[26] Zampella RA. Characterization of surface water quality along a watershed disturbance gradient. Journal of the American Water Resources Association, 1994, 30(4) : 605-611.

[27] 单保庆,尹澄清. 小流域磷污染非点源输出的人工降雨模拟研究. 环境科学, 2000,20(1):33-37.

[28] Benoit GR. Effect of agricultural management of wet sloping soil on nitrate and phosphorus in surface and surface water. Water Resources Research, 1973, 9(5) : 1296-1303.

[29] Gao C, Zhu JG, Zhu JY et al. Nitrogen export from an agriculture watershed in the Taihu Lake area, China. Environmen- 
tal Geochemistry and Health, 2004, 26(2) : 199-207.

[30］宋学宏,郭培红,孙丽萍等. 苏州市东山镇池塘养蟹面源污染现状及控制. 水资源保护,2011,27(1):63-72.

[31］王 鹏,徐爱兰. 太湖流域典型圩区农田氮素地表径流迁移特征. 农业环境科学学报,2008,27(4):1335-1339.

[32] Gaynor JD, Findlay WI. Soil and phosphorus loss from conservation and conventional tillage in corn production. Journal of Environmental Quality, 1995, 24(4) : 734-741.

[33] Davies DB, Sylvester-Bradley R. The contribution of fertilizer nitrogen to leachable nitrogen in the UK: a review. Journal of the Science of Food and Agriculture, 1995, 68(4) : 399-406.

[34] 胡玉婷, 廖千家骅,王书伟等. 中国农田氮淋失相关因素分析及总氮淋失量估算. 土壤, 2011,43(1): 19-25.

[35] 杨蓓蓓, 刘 敏, 张丽佳等. 稻麦轮作农田系统中磷素流失研究. 华东师范大学学报: 自然科学版, 2009,11 (6): $56-63$.

[36] 郭 智,肖 敏,陈留根等. 稻麦两熟农田稻季养分径流流失特征. 生态环境学报,2010,19(7):1622-1627.

[37] Min J, Shi WM, Xing GX et al. Effects of a catch crop and reduced nitrogen fertilization on nitrogen leaching in greenhouse vegetable production systems. Nutrient Cycling Agroecosystems, 2011, 91(1) : 31-39.

[38 ] Zhao X, Zhou Y, Min J et al. Nitrogen runoff dominates water nitrogen pollution from rice-wheat rotation in the Taihu Lake region of China. Agriculture, Ecosystems and Environment, 2012, 156: 1-11.

[39] Tian YH, Yin B, Yang LZ et al. Nitrogen runoff and leaching losses during rice-wheat rotations in Taihu Lake region, China. Pedosphere, 2007, 17(4) : 445-456.

[40] 聂泽宇. 太湖流域苔溪面源污染源解析与过程控制技术研究 [ 学位论文]. 杭州: 浙江大学,2011.

[41] 谢学俭. 苏南稻麦轮作农田系统土壤中磷氮的流失 [学位论文].南京:南京农业大学,2003.

[42] 李国栋, 胡正义,杨林章等. 太湖典型菜地土壤氮磷向水体径流输出与生态草带拦截控制. 生态学杂志, 2006,25 (8) :905-910.

[43] 朱普平, 常志州, 郑建初等. 太湖地区稻田主要种植方式氮磷径流损失及经济效益分析. 江苏农业科学, 2007,(3): 216-218.

[44] 夏小江, 胡清宇, 朱利群等. 太湖地区稻田田面水氮磷动态特征及径流流失研究. 水土保持学报, 2011,25 (4): 21-25.

[45] Zhao X, Zhou Y, Wang SQ et al. Nitrogen balance in a highly fertilized rice-wheat double-cropping system in southern China. Soil Science Society of America Journal, 2011, 76: 1068-1078.

[46] 俞映倞, 薛利红, 杨林章. 不同氮肥管理模式对太湖流域稻田土壤氮素渗漏的影响. 土壤学报, 2011,48(5): 988-995.

[47] 张 静, 王德建, 王 灿. 用原状土柱研究太湖地区稻麦轮作农田养分淋溶量. 土壤, 2008,40(4):591-595.

[48］李 远,单正军,徐德徽. 我国畜禽养殖业的环境影响与管理政策初探. 中国生态农业学报,2002,10(2):136-138.

[49] 奕冬梅,李士平,马 君等. 规模化奶牛场育成牛和泌乳牛产排污系数的测算. 农业工程学报, 2012,28(16): 185-189.

[50］董红敏,朱志平,黄宏坤等. 畜禽养殖业产污系数和排污系数计算方法. 农业工程学报, 2011,27(1):303-308.

[51］蒋治国,王博超, 吴冬梅等. 太湖流域生猪排污系数测算试验研究. 环境与可持续发展,2010,(2):63-65.

５2］农业部渔业局. 2010 年全国渔业经济统计公报. 中国农业信息网,2011. http://www. agri. gov. cn/V20/ZX/nyyw/ 201106/t20110628_2039578. html.

[53 ] 王德建. 基塘系统的物质循环与能量传递. 北京:中国农业出版社,1998:118-139.

[54] 施炜纲,王 博,周 昕. 蟹、鱼网围混养对草型湖泊氮磷平衡的影响. 湖泊科学, 1999,11(4):363-368.

[55] 陈家长, 胡庚东, 瞿建宏等. 太湖流域池塘河蟹养殖向太湖排放氮磷的研究. 农村生态环境, 2005,21(1):21-23.

[56] 郭鸿鹏,朱静雅,杨印生. 农业非点源污染防治技术的研究现状及进展. 农业工程学报,2008,24(4):290-295.

[57］朱兆良.关于稻田土壤供氮量的预测和平均适宜施氮量的应用.土壤, 1988,20(2):57-61.

[58］夏永秋,颜晓元. 太湖地区麦季协调农学、环境和经济效益的推荐施肥量. 土壤学报,2011,48(6):1210-1218.

５9］高祥照. 我国测土配方施肥进展情况与发展方向. 中国农业资源与区划, 2008,29(1):7-10.

[60］刘秀梅,罗奇祥,冯兆滨等. 我国商品有机肥的现状与发展趋势调研报告. 江西农业学报,2007,19(4):49-52.

[61 ] Elodie P, Julien T, Cédric C et al. Pesticide contamination interception strategy and removal efficiency in forest buffer and artificial wetland in a tile-drained agricultural watershed. Chemosphere, 2013, 91(9) : 1289-1296.

[62] Moore MT, Kröger R, Locke MA et al. Nutrient mitigation capacity in Mississippi Delta, USA drainage ditches. Environmental Pollution, 2010, 158(1): 175-184.

[63] 刘福兴, 宋祥甫, 邹国燕等. 农村面源污染治理的 “4R” 理论与工程实践一一水环境生态修复技术. 农业环境科学 学报,2013,32(11):2105-2111. 